\title{
Da diversidade agrícola à commoditização do território: os efeitos do agronegócio na Região Imediata de Alfenas - Minas Gerais
}

\section{From agricultural diversity to the commoditization of the territory: the effects of agribusiness in the Immediate Region of Alfenas - Minas Gerais}

\author{
De la diversidad agrícola a la mercantilización del territorio: los \\ efectos de la agroindustria en la Región Inmediata de Alfenas - Minas \\ Gerais
}

Flamarion Dutra Alves - flamarion.dutra@unifal-mg.edu.br Professor do Programa de Pós-graduação em Geografia da Universidade Federal de Alfenas - MG Orcid : https://orcid.org/0000-0003-0318-7301

\begin{abstract}
Resumo
O presente artigo tem como objetivo analisar a estrutura fundiária e a questão agrária regional, bem como o papel da agricultura familiar e do agronegócio, caracterizar as atividades agrícolas na região ao longo de 30 anos e entender $\mathrm{o}$ processo de commoditização do território, e ainda discutir as transformações ocorridas no espaço agrário da Região Imediata de Alfenas - Minas Gerais. Para atingir esses objetivos, foram consultados trabalhos realizados sobre a Geografia Agrária do Sul de Minas, e ainda utilizados dados secundários dos Censos Agropecuários do IBGE de 1995/96, 2006 e 2017, e da Pesquisa Agrícola Municipal do IBGE de 1988 a 2017. A agricultura não familiar corresponde a $24,2 \%$ do total de estabelecimentos e ocupa uma área de $61,3 \%$ do espaço rural. Já a agricultura familiar tem $75,8 \%$ dos estabelecimentos rurais e ocupa uma área correspondente a $38,7 \%$ do espaço rural regional. No contexto da comoditização do território, observa-se um crescimento da área plantada do café, em 12,4\%, o milho de $31,5 \%$ e a soja em mais de $1800 \%$. Essas três culturas agrícolas em 1988 ocupavam 64,9\% do território, em 2017 atingiu 86,6\% do total, confirmando assim uma commoditização do território.
\end{abstract}

Palavras-chave: Commoditização do Território, Agronegócio do café, Agricultura Familiar, Sul de Minas Gerais, Geografia Agrária.

\begin{abstract}
This article aims to analyze the land tenure structure and the regional agrarian issue, as well as the role of family farming and agribusiness, characterize agricultural activities in the region over 30 years and understand the process of commoditization of the territory, and also discuss the transformations that took place in the agrarian space of the Immediate Region of Alfenas - Minas Gerais. To achieve these objectives, studies carried out on the Agrarian Geography of the South of Minas were consulted, and secondary data from the IBGE Agricultural Census from 1995/96, 2006 and 2017, and from the IBGE Municipal Agricultural Survey from 1988 to 2017 were also used. non-family agriculture corresponds to $24.2 \%$ of the total number of establishments and occupies an area of 61.3\% of the rural space. Family farming, on the other hand, accounts for $75.8 \%$ of rural establishments and occupies an area corresponding to $38.7 \%$ of the regional rural space. In the context of commoditization of the territory, there is a growth in the area planted with coffee, by $12.4 \%$, corn by $31.5 \%$ and soy by more than $1800 \%$. These three agricultural crops in 1988 occupied $64.9 \%$ of the territory, in 2017 they reached $86.6 \%$ of the total, thus confirming a commoditization of the territory.
\end{abstract}

Key words: Commoditization of the Territory, Coffee Agribusiness, Family 
Agriculture, Southern Minas Gerais, Rural Geography.

\section{Resumen}

Este artículo tiene como objetivo analizar la estructura de tenencia de la tierra y el tema agrario regional, así como el papel de la agricultura familiar y la agroindustria, caracterizar las actividades agrícolas en la región a lo largo de 30 años y comprender el proceso de mercantilización del territorio, $\mathrm{y}$ también discutir las transformaciones. que tuvo lugar en el espacio agrario de la Comarca Inmediata de Alfenas - Minas Gerais. Para lograr estos objetivos, se consultaron los estudios realizados sobre la Geografía Agraria del Sur de Minas, así como datos secundarios del Censo Agropecuario del IBGE de 1995/96, 2006 y 2017, y de la Encuesta Agrícola Municipal del IBGE de 1988 a 2017. La agricultura no familiar corresponde al 24,2\% del total de establecimientos y ocupa una superficie del $61,3 \%$ del espacio rural. La agricultura familiar, en cambio, concentra el $75,8 \%$ de los establecimientos rurales y ocupa una superficie correspondiente al 38,7\% del espacio rural comarcal. En el contexto de la mercantilización del territorio, se observa un crecimiento en el área sembrada de café, en $12,4 \%$, maíz en $31,5 \%$ y soja en más de $1800 \%$. Estos tres cultivos agrícolas en 1988 ocuparon el 64,9\% del territorio, en 2017 alcanzaron el $86,6 \%$ del total, confirmando así una mercantilización del territorio.

Palavras-chave: Mercantilización del Territorio, Agronegocios Cafeteros, Agricultura Familiar, Sur de Minas Gerais, Geografía Rural. 


\section{Introdução}

A compreensão do espaço agrário regional tem envolvido um número maior de elementos e atores no processo de organização e produção do espaço. Com a mundialização da agricultura novos atores estão envolvidos no contexto da produção agrícola, e assim, a perspectiva local-global e campo-cidade são importantes formas de entender as dimensões que formam os arranjos espaciais.

A diferenciação dos espaços regionais é uma característica da economia globalizada, onde regiões se especializam em produtos e funções, o crédito é aplicado de forma desigual e concentrado, as redes técnicas e de circulação selecionam lugares mais vantajosos e competitivos (SANTOS, 2006, DIAS, 2009, RUA, 2005).

Os lugares estão cada vez mais integrados em redes globais, onde a seleção espacial visa atender as demandas do mercado interno, e sobretudo, externo. No caso da agropecuária não é diferente, a produção de commodity tem mobilizado uma rede de fixos e fluxos em diferentes contextos regionais-globais, que envolve corporações multinacionais, cooperativas, instituições de pesquisa, setores de logística, instituições bancárias e financeiras entre outros atores.

Por isso, ao tratarmos da produção agropecuária podemos vislumbrar estudos locais-regionais, dando ênfase aos atores que estão diretamente envolvidos nos arranjos locais, sua relação entre campo-cidade, análise da ruralidade em diferentes dimensões e fazer conexões com o cenário global que interfere na organização do espaço regional, com a implantação de multinacionais, fluxo das exportações, impactos da variação dos preços das commodities entre outros.

Dessa forma, são importantes os estudos regionais na medida que se possa entender o desenvolvimento e inserção de uma economia globalizada e como ela influencia a dinâmica local-regional, em outras palavras, quais os impactos gerados na organização do espaço regional na produção agropecuária? Houve uma substituição de culturas agrícolas por commodities ao longo do tempo? Qual o papel da agricultura familiar e como está a estrutura fundiária no contexto regional? Houve uma concentração fundiária com o desenvolvimento de commodities no espaço agrário? As cidades se especializaram funcionalmente a partir da agropecuária?

Estas são algumas questões que direcionam esse artigo, e que tem como recorte geográfico a Região Geográfica Imediata de Alfenas, onde é composta por 13 municípios de acordo com a nova proposta de regionalização do IBGE (2017)ㄹe está situada no Sul de Minas Gerais (Figura 1).

${ }^{1}$ Para saber mais sobre as Regiões Geográficas: https://www.ibge.gov.br/apps/regioes_geograficas/

ALVES, Flamarion Dutra. Da diversidade agrícola à commoditização do território: os efeitos do agronegócio na Região Imediata de Alfenas - Minas Gerais. Boletim Alfenense de Geografia. Alfenas. v. 1, n.2, p. 129-150, 2021. ISSN: 2764-1422. DOI: https://doi.org/10.29327/24.3949.1.2-10 


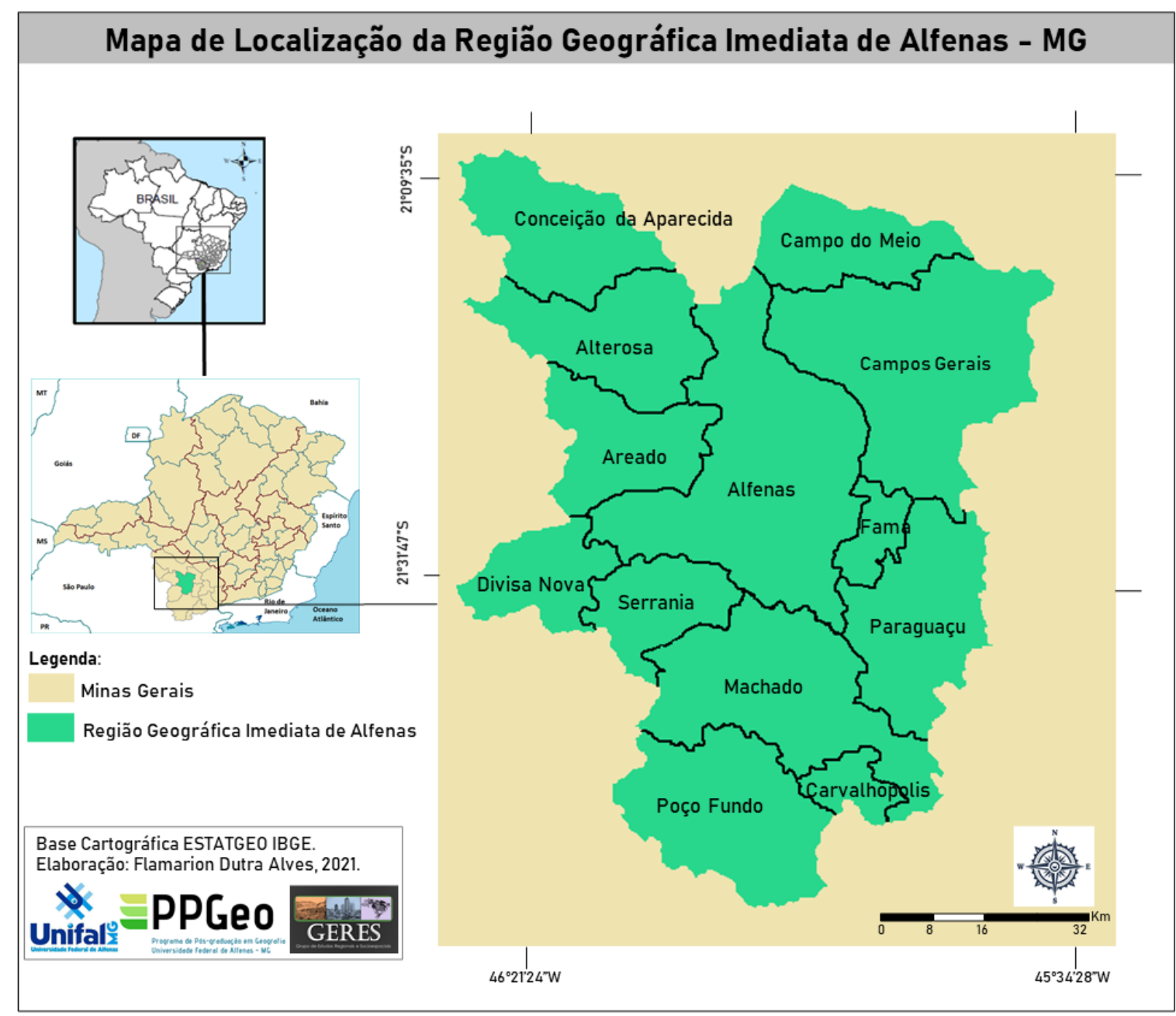

Figura 1 - Mapa de localização da Região Geográfica Imediata de Alfenas MG.

A região é composta por pequenas cidades em sua maioria (Tabela 1), e a cidade de Alfenas polariza em grande medida os setores de serviço, comércio e logística na região.

A presença de universidade pública e privadas e hospitais públicos e privados em Alfenas, denota uma atração da população regional para essa prestação de serviços (BRANQUINHO e SILVA, 2018). Além disso, na dinâmica agropecuária, a presença de armazéns de grãos, comercializadoras e exportadoras de grãos e indústrias de processamento (torrefadoras e moagem) (ALVES e LINDNER, 2020).

A Região Imediata de Alfenas está inserida na Região Intermediária de Varginha que apresenta os maiores quantitativos em área plantada e toneladas na produção de café do Brasil (ALVES e LINDNER, 2020). 
Tabela 1 - População dos municípios da Região Geográfica Imediata de Alfenas Minas Gerais, Brasil (2010).

\begin{tabular}{c|c|c|c|c|c}
\hline Município & $\begin{array}{c}\text { População } \\
\text { Urbana }\end{array}$ & $\begin{array}{c}\text { Porcentagem } \\
\text { Pop. } \\
\text { Urbana\% }\end{array}$ & $\begin{array}{c}\text { População } \\
\text { Rural }\end{array}$ & $\begin{array}{c}\text { Porcentagem } \\
\text { Pop. Rural \% }\end{array}$ & $\begin{array}{c}\text { População } \\
\text { Total }\end{array}$ \\
\hline Alfenas & 69.176 & 93,77 & 4.598 & 6,23 & 73.774 \\
\hline Alterosa & 10.002 & 72,92 & 3.715 & 27,08 & 13.717 \\
\hline Areado & 11.525 & 83,93 & 2.206 & 16,07 & 13.731 \\
\hline Campo do Meio & 10.059 & 87,65 & 1.417 & 12,35 & 11.476 \\
\hline Campos Gerais & 19.156 & 69,41 & 8.444 & 30,59 & 27.600 \\
\hline Carvalhópolis & 2.459 & 73,6 & 882 & 26,4 & 3.341 \\
\hline Conceição da & 6.199 & 63,13 & 3.621 & 36,87 & 9.820 \\
\hline Aparecida & 4.659 & 80,84 & 1.104 & 19,16 & 5.763 \\
\hline Divisa Nova & 1.515 & $\mathbf{6 4 , 4 7}$ & 835 & 35,53 & 2.350 \\
\hline Fama & 32.068 & 82,89 & 6.620 & 17,11 & 38.688 \\
\hline Machado & 16.679 & 82,39 & 3.566 & 17,61 & 20.245 \\
\hline Paraguaçu & 9.281 & 58,16 & 6.678 & 41,84 & 15.959 \\
\hline Poço Fundo & 6.576 & 87,19 & 966 & 12,81 & 7.542 \\
\hline Serrania & $\mathbf{1 9 9 . 3 5 4}$ & $\mathbf{8 1 , 7 \%}$ & $\mathbf{4 4 . 6 5 2}$ & $\mathbf{1 8 , 3 \%}$ & $\mathbf{2 4 4 . 0 0 6}$ \\
\hline TOTAL & & &
\end{tabular}

Fonte: Censo Demográfico IBGE, 2010.

Conforme a tabela 1, observa-se o predomínio de pequenas cidades, tendo 9 municípios com menos de 20 mil habitantes, 3 entre 20 e 40 mil habitantes e apenas Alfenas com mais de 70 mil habitantes, esses municípios totalizam 244.006 habitantes ${ }^{2}$ (IBGE, 2010). Além disso, a região tem uma população urbana de 81,7\% do total, com predomínio em Alfenas, Campo do Meio, Serrania e Areado com mais de $83 \%$ de seus moradores vivendo nas cidades. Já a população rural, representa $18,3 \%$ da população, com os maiores quantitativos de população rural em Poço Fundo, Conceição da Aparecida e Fama com mais de $35 \%$ de sua população.

Nesse sentido, os objetivos do artigo são: analisar a estrutura fundiária e a questão agrária regional, bem como o papel da agricultura familiar e do agronegócio na região, caracterizar as atividades agrícolas na região ao longo de 30 anos e entender a dinâmica da produção de alimentos e commodity, e entender o processo de commoditização do território, e ainda discutir as transformações ocorridas no espaço agrário da Região Imediata de Alfenas.

Para atingir esses objetivos, foram consultados trabalhos realizados sobre a Geografia Agrária do Sul de Minas, sobretudo aqueles realizados pelo Grupo de Estudos Regionais e Socioespaciais, e ainda utilizar dados secundários dos Censos Agropecuários do IBGE de 1995/96, 2006 e 2017, e da Pesquisa Agrícola

${ }^{2}$ A estimativa populacional para 2021 apontou para 226.703 habitantes. (IBGE, 2021).

ALVES, Flamarion Dutra. Da diversidade agrícola à commoditização do território: os efeitos do agronegócio na Região Imediata de Alfenas - Minas Gerais. Boletim Alfenense de Geografia. Alfenas. v. 1, n.2, p. 129-150, 2021. ISSN: 2764-1422. DOI: $\underline{\text { https://doi.org/10.29327/243949.1.2-10 }}$ 
Municipal do IBGE de 1988 a 2017, a fim de compreender a dinâmica agrícola e fundiária da região, buscando compreender a região em diferentes momentos, considerando as diferenças entre municípios e em temporalidades distintas.

\section{Agricultura familiar, Agronegócio e Cidades do Café}

As atividades agropecuárias estão presentes no contexto socioeconômico de muitos municípios brasileiros. A ruralidade econômica perpassa o espaço agrário e atinge várias esferas da vida cotidiana das cidades onde essas atividades predominam. Entre cidades rurais e cidades do agronegócio, fica nítido como o território brasileiro apresenta uma herança rural na organização socioespacial, e ainda mais, como setores políticos e socioculturais reproduzem valores e interesses das várias dimensões do mundo rural. Nessa perspectiva, do campocidade Kageyama (2008) vai dizer que:

Os espaços rurais que ficam no interior desses sistemas urbanos interconectados, liderados pelas cidades médias, podem ser concebidos como "clusters agroindustriais", e são esses espaços que têm potencial para o desenvolvimento econômico. (KAGEYAMA, 2008, p.33)

Nesse sentido, o estudo da relação campo-cidade é pertinente para analisar a produção agropecuária e seus efeitos na organização regional. A modernização da agricultura e sua inserção no meio técnico-científico-informacional tem criado regiões competitivas como o caso cafeeiro na região de Alfenas (SANTOS, 2014, GUIDA e ALVES, 2012)

Observa-se a dependência econômica de parte dos agricultores familiares que estão envolvidos na cafeicultura na região de Alfenas, e que "apesar das dificuldades, a princípio, a agricultura familiar continuará produzindo café para o agronegócio, até porque não conseguem vislumbrar outra alternativa na agricultura" (VALE, 2018, p.45).

A questão da mão-de-obra migrante nos períodos da colheita do café são processos constantes na organização produtiva e sociocultural da cafeicultura sul mineira. Essa mobilidade populacional gerada pela atividade agrícola, ultrapassa os limites do espaço agrário e dinamiza as cidades, sobretudo as pequenas, da região.

No contexto urbano-regional, a rede de cidades é formada por cidades pequenas e Alfenas, como uma cidade média, que centraliza e polariza os municípios da Região Imediata de Alfenas (ALVES, 2018, BRANQUINHO e SILVA, 2018).

A dinâmica agropecuária tem reverberações importantes no comércio, serviços e agroindústria regional, o emprego na cidade é condicionado em parte, a atividades derivadas do espaço rural, integrando campo e cidade. Proporcionando a essas cidades pequenas, serem consideradas cidades rurais, do agronegócio ou cidades do café.

A ruralidade é bastante presente nesses municípios devido ao agronegócio do café (ALVES, 2020), que consolida a região sul mineira como a principal produtora de café do Brasil, com aproximadamente $25 \%$ da produção nacional. 
Nesse sentido, os serviços, comércio e algumas indústrias mantém uma relação com a cafeicultura direta, seja nos vários processos da cadeia produtiva, do plantio, cultivo, assistência técnica, inovações, comercialização ou pós-colheita.

Em 2006 na Região Geográfica Imediata de Alfenas, as empresas de Cultivo, Torrefação e Moagem de café totalizavam 41 unidades, sendo 14 delas em Alfenas, 8 em Machado e 4 em Paraguaçu e Campos Gerais. Já em 2018, o total dessas empresas aumentou para 73, sendo 19 em Alfenas, 18 em Machado, $11 \mathrm{em}$ Campos Gerais e 6 em Paraguaçu (IBGE, 2018). Percebe-se que o incremento na atividade cafeeira se especializou na região, ampliando o número de empresas a esse setor, consolidando a cidade média de Alfenas como principal transformadora dessa commodity, mas vê as cidades de Machado e Campos Gerais com crescimento significativo, sobretudo, por serem menores e terem na cafeicultura a grande geração e renda e emprego de suas cidades. Diferentemente de Alfenas, que por ser uma cidade polo, tem a economia diversificada com o setor educacional e de saúde bem complexo e que atende a região.

A relação campo-cidade na dimensão econômica vai se estabelecer com a população economicamente ativa agrícola contrastando com a população rural desses municípios (Tabela 2).

Tabela 2 - Percentual de trabalhadores rurais acima da população rural nos municípios da Região Geográfica Imediata de Alfenas - Minas Gerais, Brasil (2017).

\begin{tabular}{l|c|c|c}
\hline \multicolumn{1}{c|}{ Município } & $\begin{array}{c}\text { População } \\
\text { Rural }\end{array}$ & $\begin{array}{c}\text { Pessoal Ocupado na } \\
\text { Agropecuária }\end{array}$ & $\begin{array}{c}\text { Porcentagem acima } \\
\text { da população rural }\end{array}$ \\
\hline Alfenas & 4.598 & 6.263 & $36,2 \%$ \\
\hline Alterosa & 3.715 & 5.415 & $45,76 \%$ \\
\hline Areado & 2.206 & 2.909 & $31,86 \%$ \\
\hline Campo do Meio & 1.417 & 3.496 & $146,7 \%$ \\
\hline Campos Gerais & 8.444 & 28.293 & $235,06 \%$ \\
\hline Carvalhópolis & 882 & 935 & $158,3 \%$ \\
\hline Conceição da & 3.621 & 9.353 & $65,6 \%$ \\
\hline Divarisa Nova & 1.104 & 1.828 & - \\
\hline Fama & 835 & 572 & $29,29 \%$ \\
\hline Machado & 6.620 & 8.559 & $54,3 \%$ \\
\hline Paraguaçu & 3.566 & 5.503 & $548,3 \%$ \\
\hline Poço Fundo & 6.678 & 5.679 & $\mathbf{8 0 , 9 \%}$ \\
\hline Serrania & 966 & 6.263 & $\mathbf{8 0 . 7 7 9}$ \\
\hline \multicolumn{1}{c|}{ TOTAL } & $\mathbf{4 4 . 6 5 2}$ & & \\
\hline
\end{tabular}

Fonte: Censo Demográfico do IBGE, 2010; Cadastro Central de Empresas, IBGE, 2018.

Elaboração: Flamarion Dutra Alves.

A tabela 2 exprime bem a questão das cidades rurais no sul de Minas Gerais, ou seja, a população que trabalha em atividades agropecuários no campo é mais de $80 \%$ superior a população rural. Apenas dois municípios tem a 
população ocupada na agropecuária inferior a população rural, Fama e Poço Fundo, os demais necessitam de pessoas que residem nas cidades para exercer as atividades agropecuárias, seja no ano todo ou em períodos de colheita com trabalho temporário.

Além disso, a questão de gênero no trabalho rural evidencia grande presença masculina, pois 73,64\% dos trabalhadores são homens e 26,36\% são mulheres. Corroborando com a tendência de migração para a cidade das mulheres, seja pelas oportunidades de estudo e trabalho em comércio e serviços, bem como o distanciamento do patriarcado tradicional do espaço rural brasileiro

\section{A estrutura fundiária e questão agrária}

A concentração de terras no Brasil é um problema estrutural, que advém de seu processo histórico-geográfico de ocupação territorial, marcado por sistemas que valorizaram a monocultura, latifúndio e mão-de-obra escrava. Conforme dados do último Censo agropecuário de 2017, aponta-se que no Brasil $76,9 \%$ dos estabelecimentos rurais são da agricultura familiar e $23,1 \%$ são caracterizados como não familiares. Entretanto, a área ocupada das propriedades rurais da agricultura familiar atinge apenas $23 \%$ do espaço rural brasileiro, enquanto que as médias e grandes propriedades ocupam $77 \%$ do espaço rural brasileiro.

Na Região Imediata de Alfenas, a concentração de terras está presente conforme mostra a figura 2.

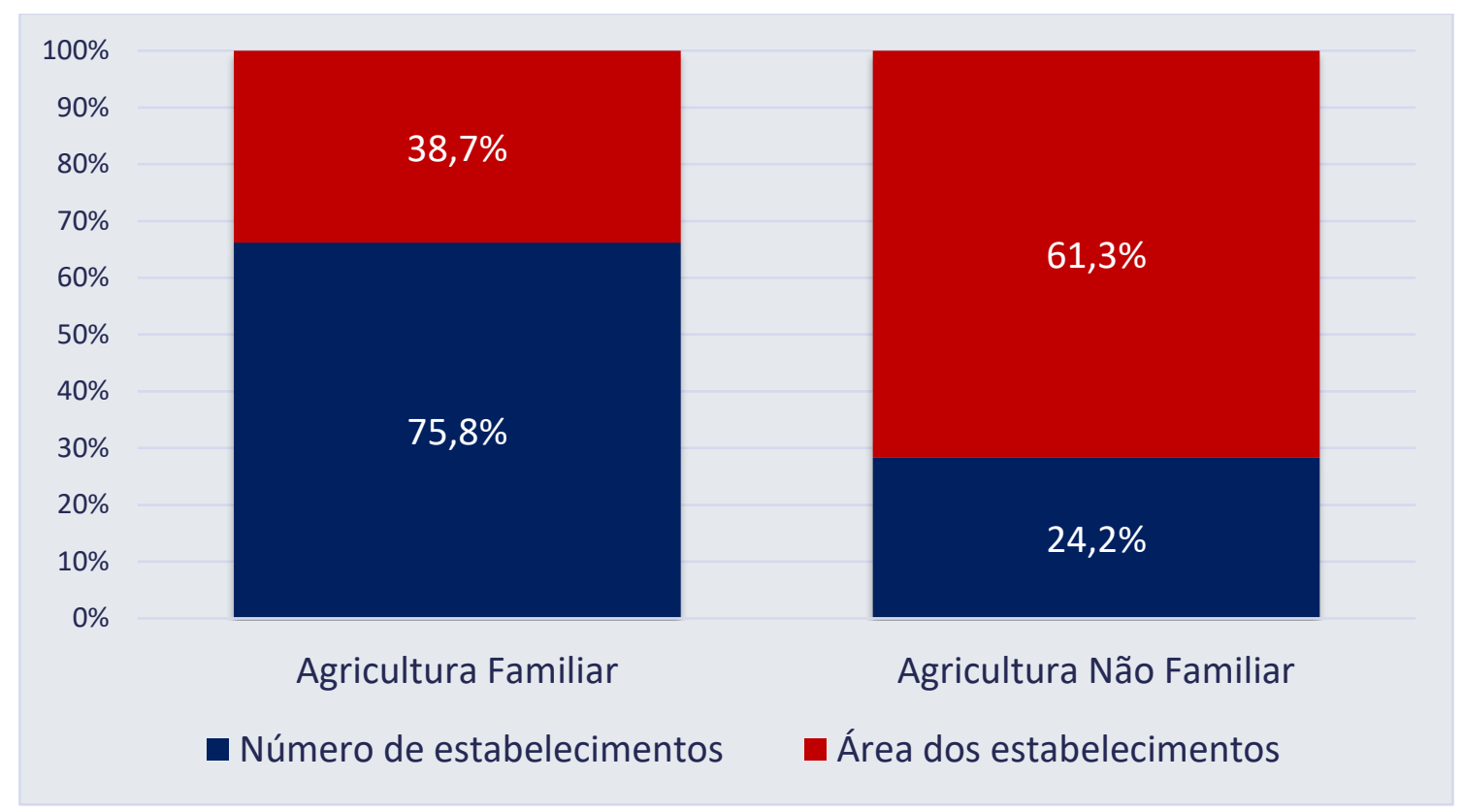

Figura 2 - Percentual do número e área dos estabelecimentos rurais na Região Imediata de Alfenas-MG, 2017.

Fonte: Censo Agropecuário do IBGE, 2017. Elaboração: Flamarion Dutra Alves.

A estrutura fundiária nos municípios que compõem a Região Imediata de Alfenas confirma uma concentração de terras, são estabelecimentos rurais não familiares, ou seja, aqueles que são dirigidos por empresas, pessoa jurídica, 
sociedades ou ainda são chamadas de agricultura patronal. Esses correspondem a 3.514 estabelecimentos rurais, $24,2 \%$ do total e ocupam uma área de 235.975 hectares, sendo $61,3 \%$ do espaço rural da região. Já a agricultura familiar tem 11.037 estabelecimentos rurais na região, que corresponde a $75,8 \%$ do total, e ocupa uma área de 149.003 hectares, que corresponde a apenas $38,7 \%$ do espaço rural regional.

Essa concentração é mais acentuada nos municípios de Serrania, onde a agricultura não familiar ocupa $86,4 \%$ do espaço rural, seguido por Alfenas com 83,5\% e Machado com 65,4\% do seu espaço rural é ocupado pela agricultura não familiar. Esses valores acima da média regional, podem ser explicados pela presença de propriedades rurais ligadas a cafeicultura, que estão altamente integradas com o mercado externo na produção de commodity, inseridos na mundialização da agricultura, exemplificando o processo de commoditização do território.

Entretanto, a presença da agricultura familiar é majoritária em termos territoriais em alguns municípios da região, como é o caso de Carvalhópolis onde 83,9\% do espaço rural é territorializado pela agricultura familiar, seguido de Poço Fundo com 72,9\% do espaço rural ocupado pela agricultura familiar e Alterosa com $61,3 \%$ do espaço rural.

Considerando os estratos de propriedades rurais até 100 hectares, constata-se uma diferenciação espacial na região, apontando para divergência na organização espacial e com diferentes formas de ocupação (Figura 3) 


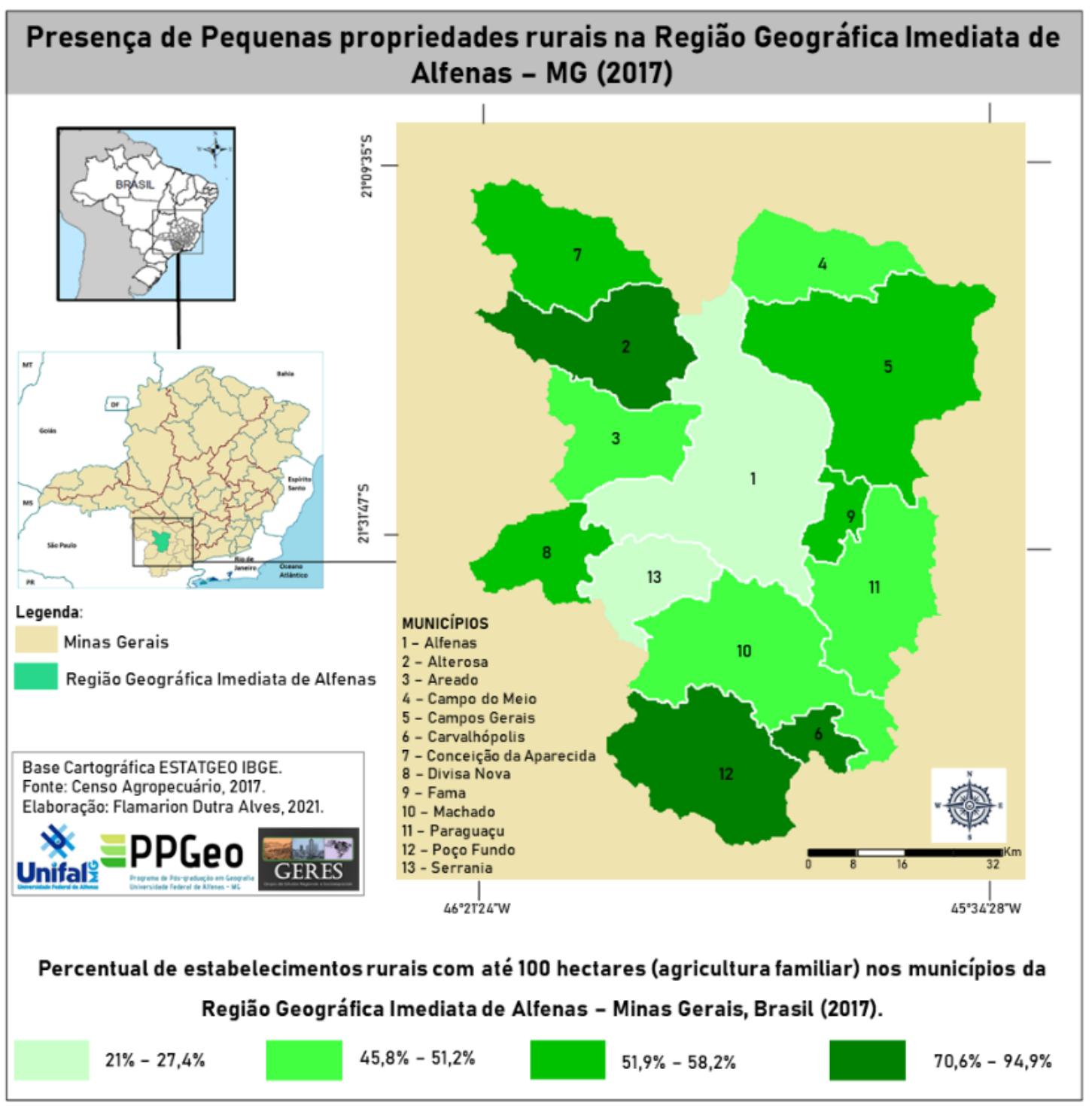

Figura 3 - Percentual de pequenas propriedades rurais na Região Geográfica Imediata de Alfenas - MG, 2017.

Fonte: Censo Agropecuário do IBGE, 2017. Elaboração: Flamarion Dutra Alves.

Observa-se que os municípios de Alfenas e Serrania tem uma baixa organização territorial com propriedades rurais com menos de 100 hectares, demostrando uma presença significativa de médias e grandes propriedades rurais. Já os municípios de Alterosa, Carvalhópolis e Poço Fundo tem mais de $70 \%$ das propriedades rurais com até 100 hectares. Geralmente, são nessas propriedades rurais, com base familiar, que são produzidos grande parte da diversidade alimentar que abastece os mercados, feiras e propicia uma segurança alimentar para a população.

Ao longo de três décadas, observa-se um aumento da área ocupada por grandes propriedades rurais na região (Figura 4) 


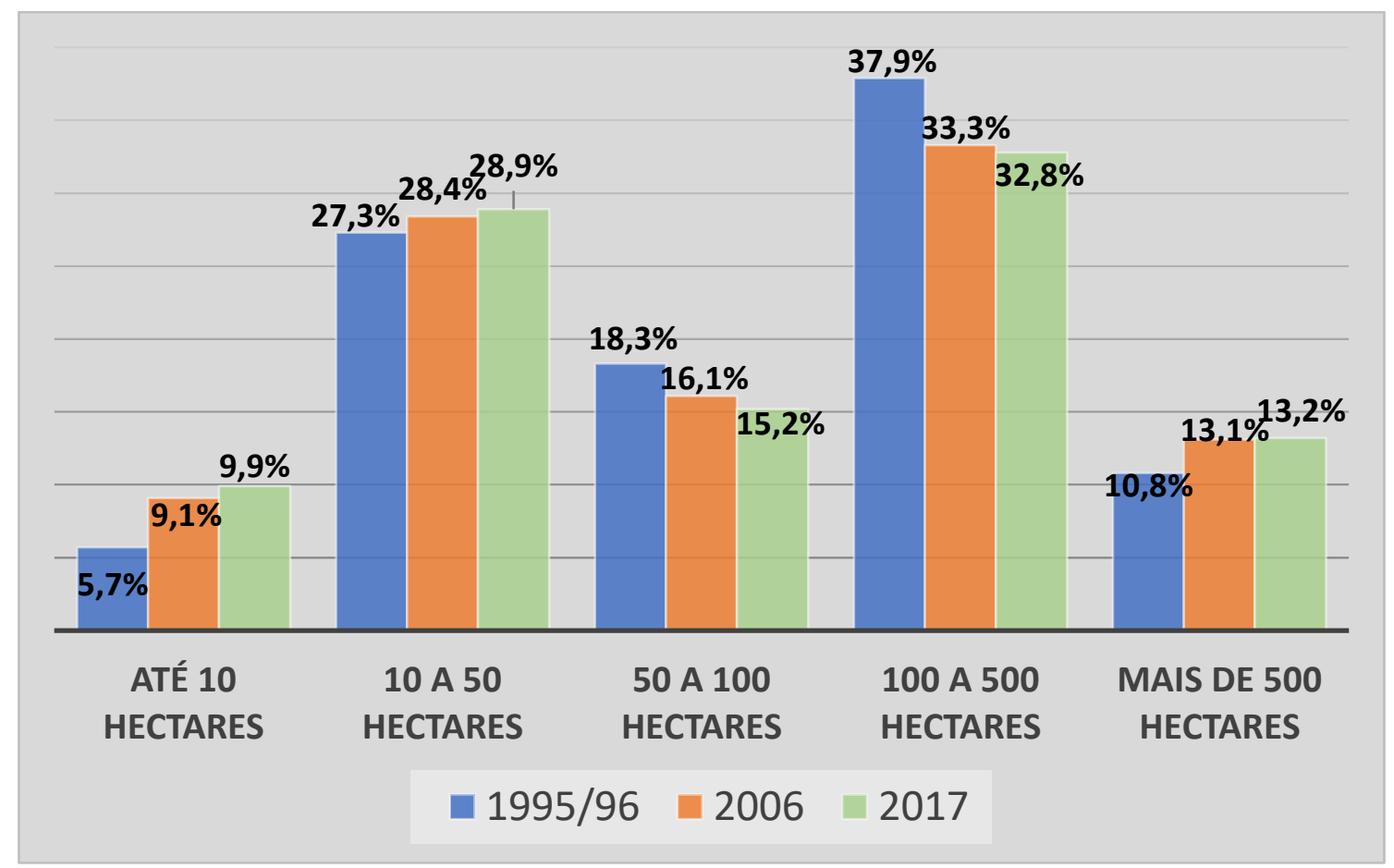

Figura 4 - Gráfico com a porcentagem da área dos estabelecimentos rurais, por estratos, na Região Imediata de Alfenas-MG (1995-96, 2006, 2017)

Fonte: Censos Agropecuários do IBGE (1995/96, 2006 e 2017). Elaboração: Flamarion Dutra Alves.

Os minifúndios na região têm aumentado em termos percentuais ao longo dos últimos três censos agropecuários, as propriedades com até 10 hectares subiram de 5,7\% para 9,9\%, na mesma tendência, as propriedades de 10 até 50 hectares, passaram de 27,3\% em 1995 para 28,9\% da área total da região. Esse segmento de área corresponde em grande medida a agricultura familiar, que foi se reorganizando ao longo das últimas três décadas.

Já o estrato das grandes propriedades vem aumentando a cada censo agropecuário, passou de 10,8\% da área total da região em 1995 para 13,2\% em 2017. Essas grandes propriedades têm se voltado especialmente para a produção de commodity, café, soja e milho.

Diante desse contexto de concentração de terras, a reforma agrária é um processo necessário para tentar corrigir essa disparidade fundiária, que tem implicações socioeconômicas e ambientais graves para o espaço rural brasileiro.

Na Região Imediata de Alfenas, tem ocorrido desde a década de 1990 o processo de luta pela terra e a conquistas de territórios para trabalhadores oriundos do Movimento dos Trabalhadores Rurais Sem-Terra (MST), no município de Campo do Meio. As desapropriações têm ocorrido na área da antiga Usina Ariadnópolis, que teve sua falência total decretada em 1996 (VALE et al, 2019; LUCAS e VALE, 2014; COCA et al, 2018, SEDA et al, 2018).

Desde então, foram criados 2 assentamentos rurais, o Assentamento Primeiro do Sul, em 1997, com 888 hectares e com 42 famílias assentadas e o Assentamento Nova Conquista II, em 2014, com 300 hectares e com 12 famílias assentadas (INCRA, 2017). Além desses assentamentos, há constantes conflitos e conquistas nesses territórios em disputa, e são contabilizados 13 acampamentos 
ocupando algo em torno de 4 mil hectares (Figura 5) com aproximadamente 460 famílias (SADA et al, 2018).

Os dados sobre a estrutura fundiária de Campo do Meio evidenciam o impacto da instalação dos assentamentos rurais na organização espacial do campo. Em 1995, apenas 30,2\% da área dos municípios era ocupada por estabelecimentos rurais de até 100 hectares, já em 2017, após a instalação dos dois assentamentos e da presença dos acampamentos, 48,3\% do espaço rural municipal é ocupado por estabelecimentos rurais de até 100 hectares.

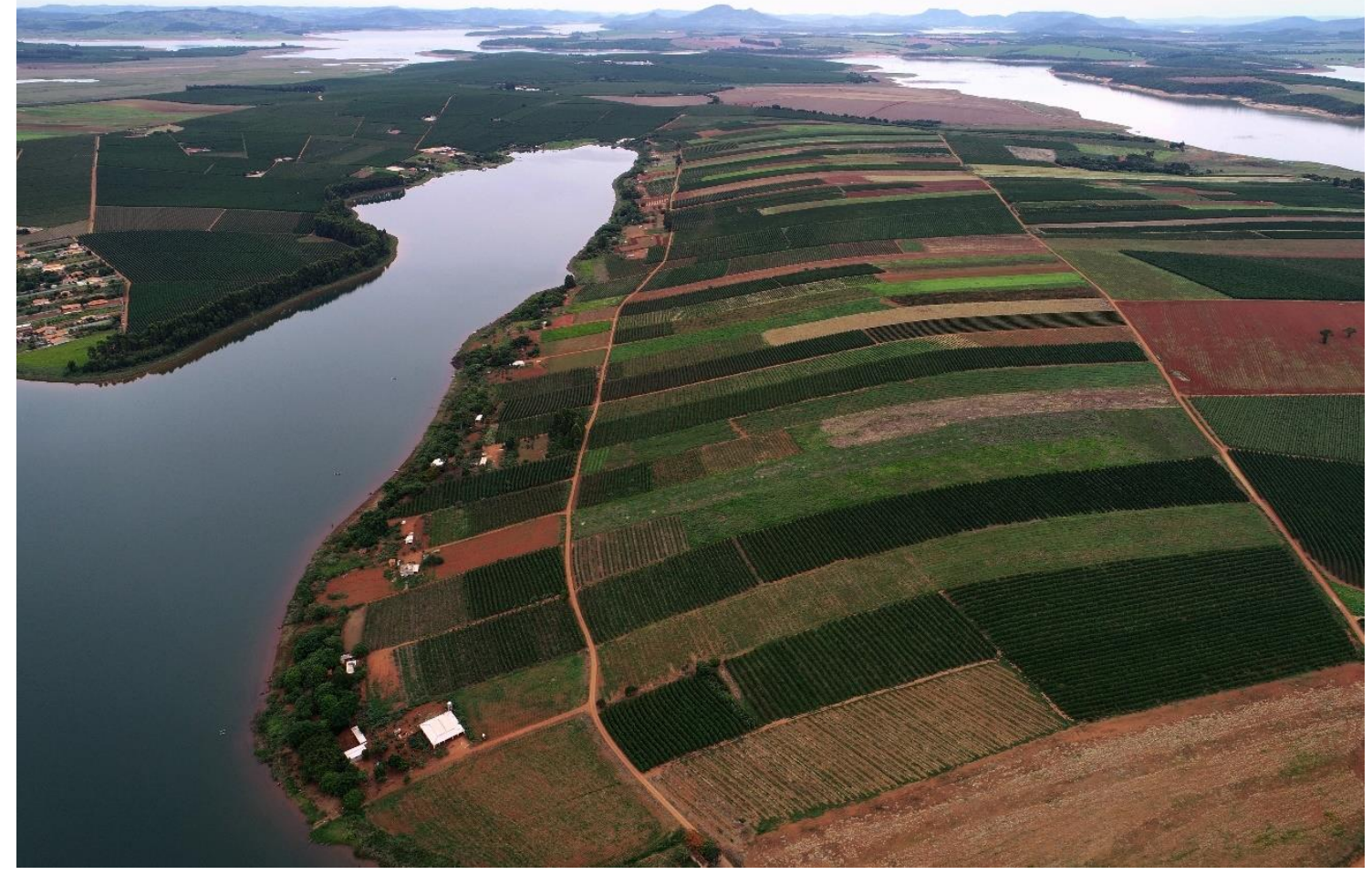

Figura 5 - Fotografia aérea do Acampamento Quilombo Campo Grande em Campo do Meio-MG, 2018.

Fonte: Trabalho de campo, 2018.

Na figura 5, observa-se duas territorialidades distintas no espaço rural, do lado direito vários lotes do acampamento, com uma diversidade produtiva e presença de várias famílias ocupando esse espaço, compondo uma diversidade sociocultural. Do lado esquerdo, nota-se somente a produção de café de um latifúndio do maior produtor de café da América Latina, com vazios demográficos e socioculturais, ou seja, os contrastes existentes na estrutura fundiária são marcados pelos conflitos e embates no município de Campo do Meio, que se alicerçam na crescente commoditização do território.

\section{Da policultura a monocultura: a commoditização do território}

Com a expansão do agronegócio no território brasileiro e a inserção da mundialização da agricultura, a dinâmica da produção de alimentos tem sido comandada por grandes corporações e empresas multinacionais que monopolizam o mercado alimentar. 
Além da redução da diversidade agrícola, tem-se um aumento da dependência externa e do mercado financeiro, devido aos preços futuros e dolarizados das commodity, o que gera impactos diretos no preço dos alimentos e da inflação.

A partir de Galeano (2019, p.7), quando diz que "a monocultura é uma prisão. A diversidade, ao contrário, liberta”, entendemos que o território que suprime elementos da diversidade, sejam eles vegetais ou animais, tem um impacto sociocultural tão devastador quanto econômico. Nesse sentido, a commoditização do território se caracteriza pela diminuição de variedades agrícolas associadas a uma expansão de grãos e cultivos, destinados a atender o mercado externo e agroindústrias nacionais. Essa commoditização do território tende a homogeneizar a paisagem rural, reduzindo a presença de pessoas, a diversidade de objetos e ações na morfologia socioespacial, da diversidade da agricultura familiar a monocultura da grande propriedade, e por fim, essa commoditização é amparada e subsidiada com recursos do Estado, em formas de políticas de crédito e financiamento. Apenas para exemplificar, em 2019, o crédito rural no Brasil atingiu a marca de 178 bilhões de reais 3 , e desse valor apenas $14,5 \%$ foi destinado ao PRONAF, que atende a agricultura familiar, ou seja, os sucessivos governos ao longo do século XX e XXI, subsidiam largamente a commoditização do território brasileiro.

Em 30 anos de análise da produção agrícola na Região Imediata de Alfenas, observa-se um panorama devastador do ponto de vista alimentar e da diversidade (Tabela 3), em prol do aumento de commodities, neste sentido, podese afirmar que ocorre uma comoditização do território.

Tabela 3 - Área plantada de culturas agrícolas na Região Imediata de Alfenas em 1988 e 2017.

\begin{tabular}{c|c|c}
\hline \multirow{2}{*}{ Cultura agrícola } & $\mathbf{1 9 8 8}$ & $\mathbf{2 0 1 7}$ \\
\cline { 2 - 3 } & \multicolumn{2}{|c}{ Área plantada em hectares } \\
\hline Alho & 76 & 4 \\
\hline Arroz & 22.101 & 80 \\
\hline Banana & 608 & 343 \\
\hline Batata-Inglesa & 1.740 & 630 \\
\hline Café & 73.875 & 83.034 \\
\hline Cana-de-açúcar & 13.437 & 6.675 \\
\hline Feijão & 11.875 & 11.528 \\
\hline Girassol & 0 & 465 \\
\hline Laranja & 3.474 & 143 \\
\hline Limão & 39 & 13 \\
\hline Mandioca & 250 & 105 \\
\hline Milho & 24.950 & 32.805 \\
\hline Soja & 950 & 17.341 \\
\hline Tangerina & 349 & 36 \\
\hline Tomate & 46 & 135 \\
\hline Total & $\mathbf{1 5 3 . 7 7 0}$ & $\mathbf{1 5 3 . 3 3 7}$ \\
\hline
\end{tabular}

3 Dados disponíveis na Matriz de Dados do Crédito Rural no Banco Central do Brasil. Acesso em: https://www.bcb.gov.br/estabilidadefinanceira/micrrural

ALVES, Flamarion Dutra. Da diversidade agrícola à commoditização do território: os efeitos do agronegócio na Região Imediata de Alfenas - Minas Gerais. Boletim Alfenense de Geografia. Alfenas. v. 1, n.2, p. 129-150, 2021. ISSN: 2764-1422. DOI: $\underline{\text { https://doi.org/10.29327/243949.1.2-10 }}$ 
Fonte: Pesquisa Agrícola Municipal, 1988 e 2017. Elaboração: Flamarion Dutra Alves.

No contexto da comoditização do território, observa-se um crescimento da área plantada do café, em 12,4 \%, o milho de $31,5 \%$ e a soja em mais de $1800 \%$. Essas três culturas agrícolas em 1988 ocupavam 64,9\% do território, em 2017 atingiu 86,6\% do total, confirmando assim uma commoditização do território.

A área plantada de alimentos que estão na dieta da população e que abastecem os centros urbanos, tem diminuído ao longo das últimas três décadas. Há uma comoditização do espaço rural na Região Imediata de Alfenas, ou seja, da diversificação alimentar à uma monocultura de grãos para exportação e servindo de matéria-prima para rações e outros fins.

Os alimentos que mais perderam território na região foram o arroz, que perdeu 99\% da área de 1988, ficando com apenas 80 hectares, a laranja, que teve sua área reduzida em 96\% em 30 anos, ocupando apenas 143 hectares na região, o alho que também teve sua área reduzida em 94\%, e em 2017 ocupa apenas 4 hectares, a batata inglesa que também teve uma redução de $63 \%$ em 30 anos, e a mandioca, que teve redução de área em 58\%, e em 2017 ocupa apenas 105 hectares na região.

Esses alimentos são característicos da agricultura familiar e estão presentes na dieta da população brasileira, ou seja, esses espaços foram ocupados por outras culturas agrícolas, que estão no bojo do agronegócio, como o café, soja e milho.

A seguir, analisaremos a periodização de algumas culturas agrícolas na região (Figura 6), para entender esse processo de substituição dos alimentos por commodity.

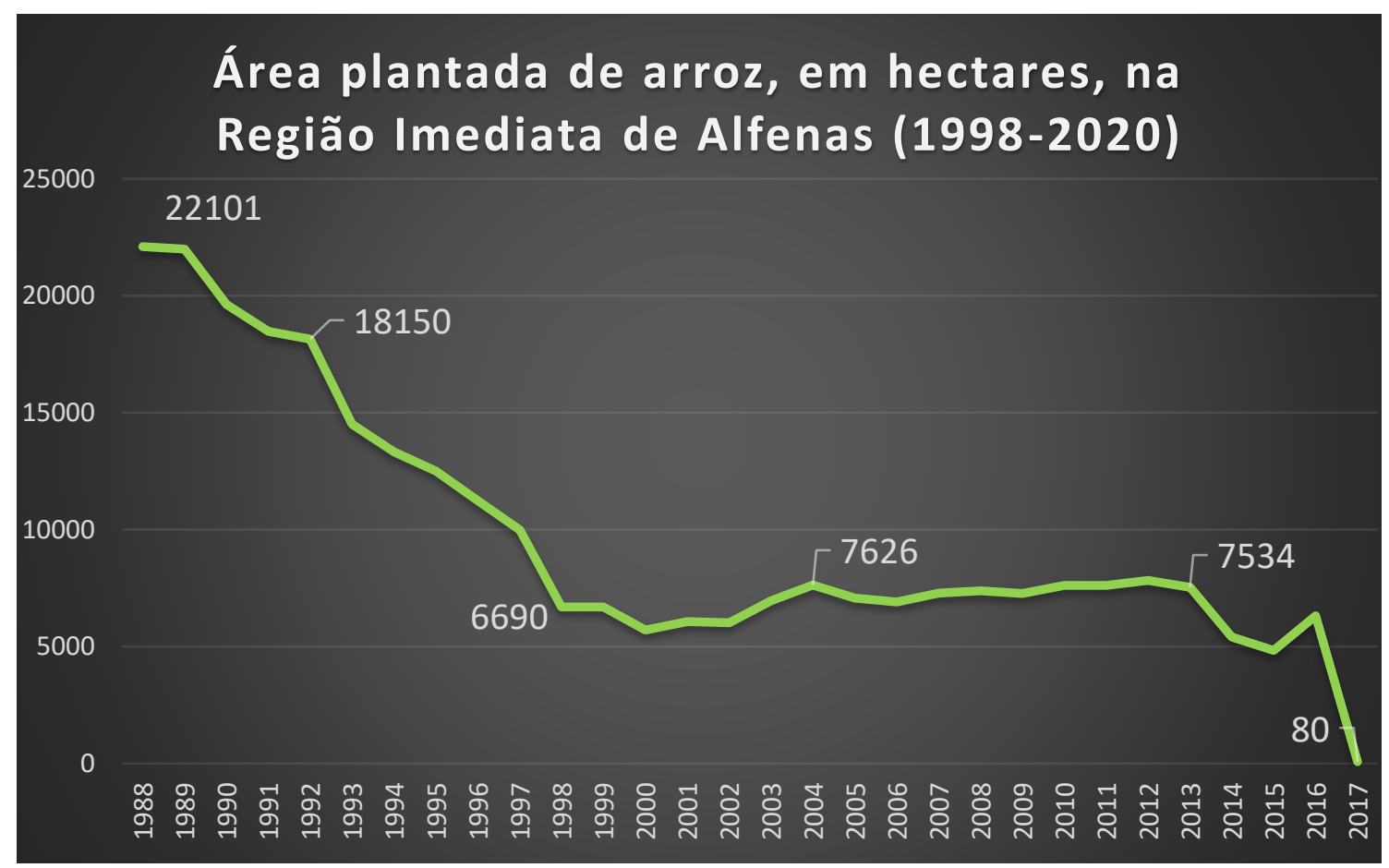

Figura 6 - Área plantada de arroz na Região Imediata de Alfenas - MG, entre 1988 e 2017.

Fonte: Pesquisa Agrícola Municipal do IBGE, 1988-2017. Elaboração: Flamarion Dutra Alves. 
A rizicultura perdeu 99\% da sua área em 30 anos na região de Alfenas, em 1988 havia 22.101 hectares, onde o município de Campos Gerais detinha quase 6 mil hectares, seguido de Campo do Meio com 5.775 ha e Alfenas com 4278 ha. Desde então, houve uma queda significativa e desde 1998, a área plantada oscila muito pouco, e alguns municípios praticamente reduziram a área plantada arroz a poucos hectares, como é o caso de Campo do Meio que tem apenas 20 hectares em 2017 e Campos Gerais somente 65 hectares.

Ainda entre as culturas agrícolas que perderam espaço, destaca-se a batata-inglesa (Figura 7).

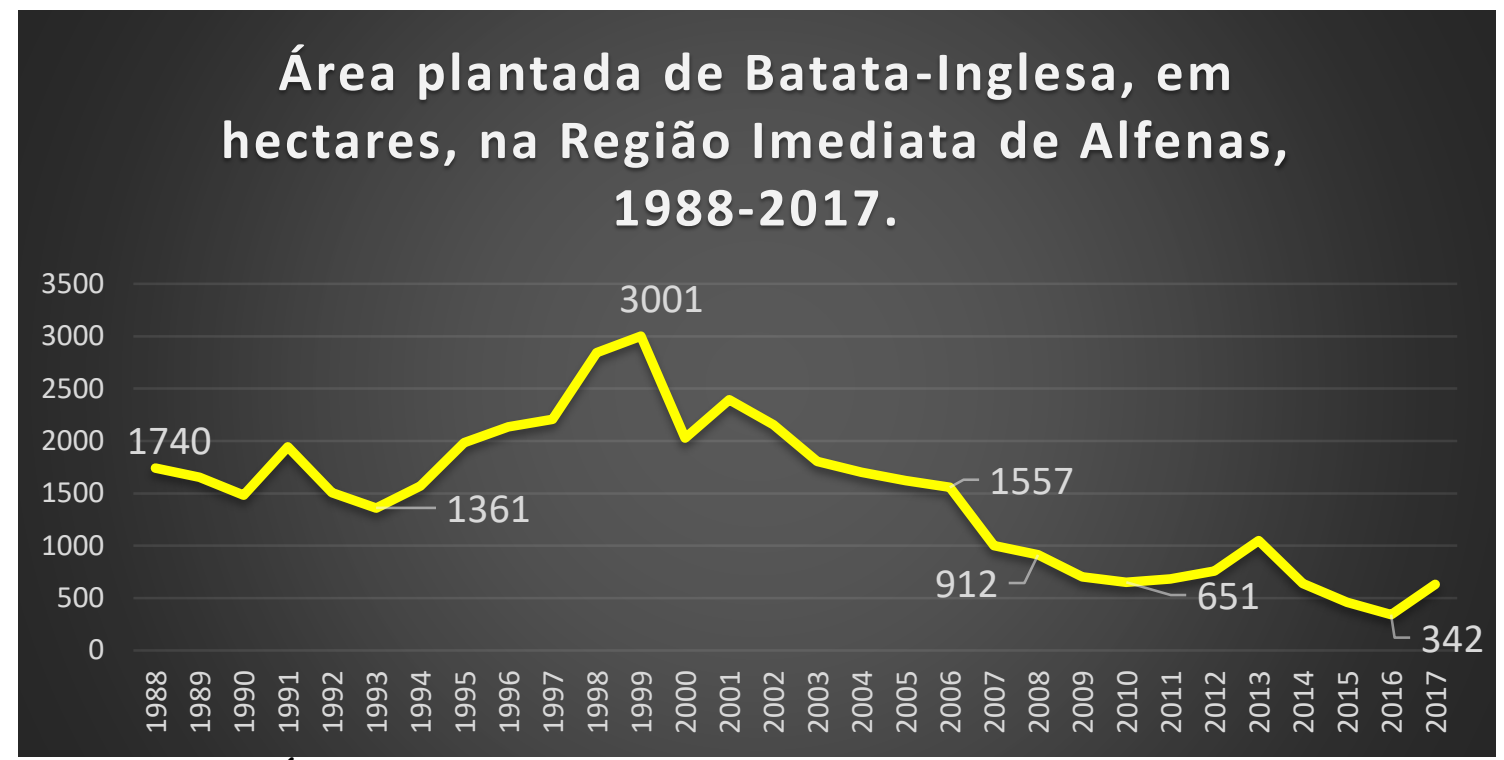

Figura 7 - Área plantada de batata-inglesa na Região Imediata de Alfenas MG, entre 1988 e 2017.

Fonte: Pesquisa Agrícola Municipal do IBGE, 1988-2017. Elaboração: Flamarion Dutra Alves.

Outro alimento típico da agricultura familiar e presente na dieta da população é a batata. Essa cultura agrícola teve uma queda de 63\% de sua área plantada e 30 anos. Houve oscilações nesse período, quando atingiu em 1999 o ápice da área plantada com mais de 3 mil hectares, porém, a queda foi significativa, chegando a apenas 342 hectares plantados em 2016. Entre os municípios que mais perderam área ou deixaram de produzir batata foram Areado, que em 1988 tinha 274 ha e em 2017 não existe mais esse cultivo, Alfenas que tinha 780 ha em 1988 e em 2017 detinha 300 ha de batata.

Outra cultura típica da agricultura familiar é a mandioca (Figura 8), esta também teve sua área reduzida nesse período de análise. 


\section{Área plantada de Mandioca, em hectares, na Região Imediata de Alfenas (1988-2017)}

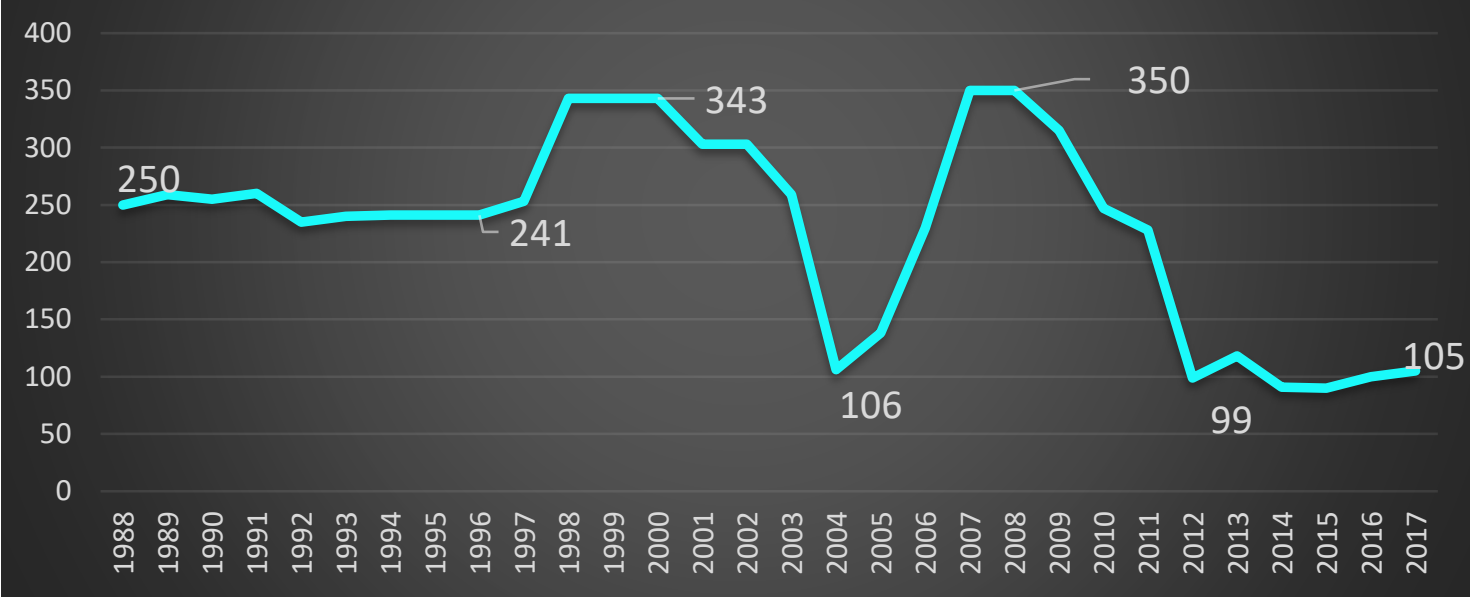

Figura 8 - Área plantada de mandioca na Região Imediata de Alfenas - MG, entre 1988 e 2017.

Fonte: Pesquisa Agrícola Municipal do IBGE, 1988-2017. Elaboração: Flamarion Dutra Alves.

A mandioca é considerada um alimento tradicional e com muitos usos na alimentação da população brasileira, e amplamente produzida pela agricultura familiar em diversas regiões do país. Entretanto, sua área na Região Imediata de Alfenas foi reduzida nesses 30 anos de análise. Em 1988 a mandiocultura ocupava 250 hectares, e todos municípios da região tinham áreas plantadas de mandioca, Alfenas com 50 hectares, Machado com 45 hectares e Campos Gerais com 41 hectares eram os principais produtores. Já em 2017, a área plantada na região atingiu apenas 105 hectares, e destes apenas 7 municípios produziram, sendo Alfenas o principal com 50 hectares, Campos Gerais 24 hectares e Paraguaçu com 10 hectares.

De forma geral, os alimentos produzidos pela agricultura familiar e típicos de uma policultura agrícola, foram substituídos por commodities na região, destacaremos dois cultivos que ocupam mais de $65 \%$ do espaço rural da região, a soja e o café (Figuras 9 e 10). 


\section{Área plantada de soja, em hectares, na Região Imediata de Alfenas, 1988-2017}

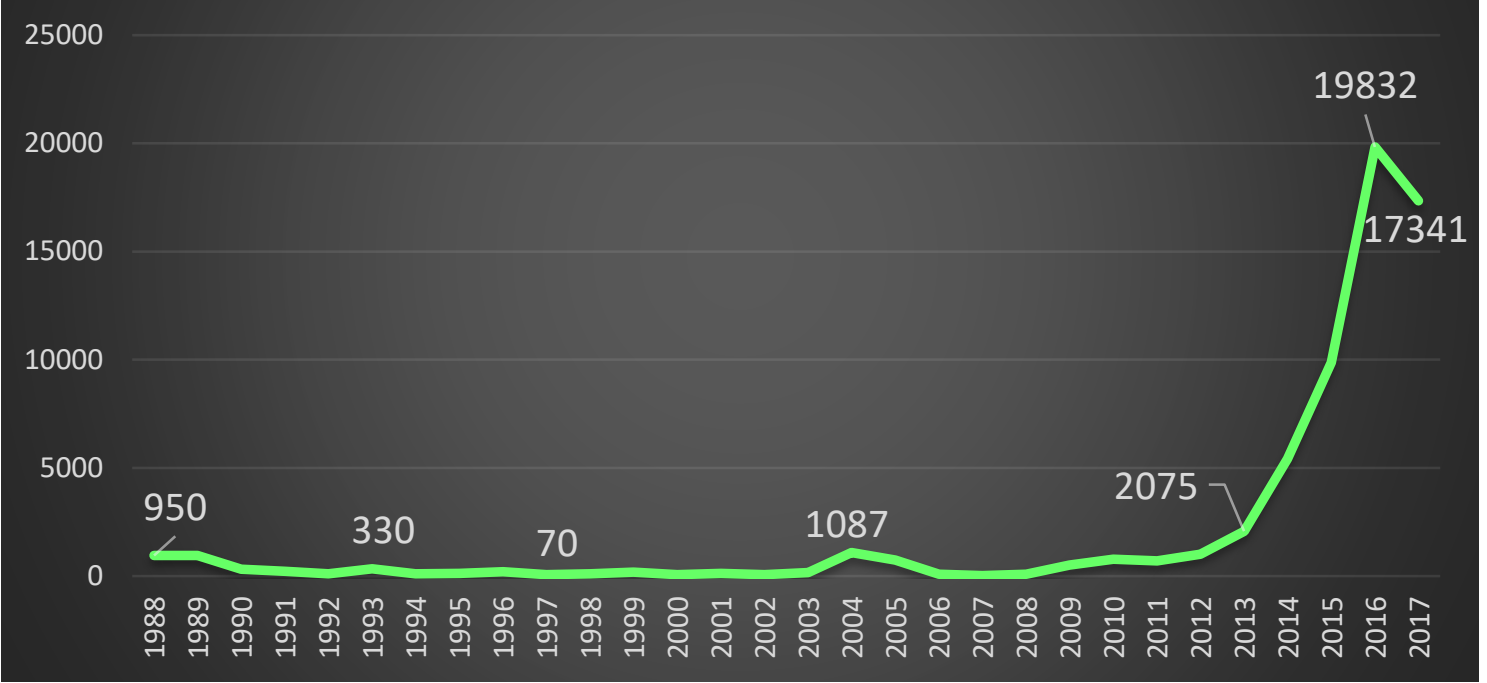

Figura 9 - Área plantada de soja na Região Imediata de Alfenas - MG, entre 1988 e 2017.

Fonte: Pesquisa Agrícola Municipal do IBGE, 1988-2017. Elaboração: Flamarion Dutra Alves.

A soja ocupará na região um espaço tardio, sobretudo pós década de 2010. Diferente de outras regiões agrícolas, onde a soja despontou na década de 1960 e 1970, como no sul do Brasil. Na Região Imediata de Alfenas, em 1988 apenas quatro municípios produziam soja, Alfenas com 500 hectares, Campo do Meio com 394 hectares, Machado com 36 hectares e Divisa Nova com 20 hectares. Essa dinâmica irá até 2012, onde poucos municípios da região estavam envolvidos na sojicultura e a área plantada pouco passava de 1000 hectares. A partir de 2013 haverá um crescimento significativo e em 2017 apenas dois municípios da região não produziam soja, Fama e Poço Fundo, sendo os mais significativos Alfenas com 5300 hectares, Machado com 3550 hectares, Paraguaçu com 1850 hectares e Campos Gerais com 1720 hectares.

Em 30 anos, de 1988 a 2017, o café é a cultura agrícola que predomina territorialmente na região (Figura 10), nesse período de análise mais da metade da área de lavouras permanentes e temporárias são ocupadas pela cafeicultura. 


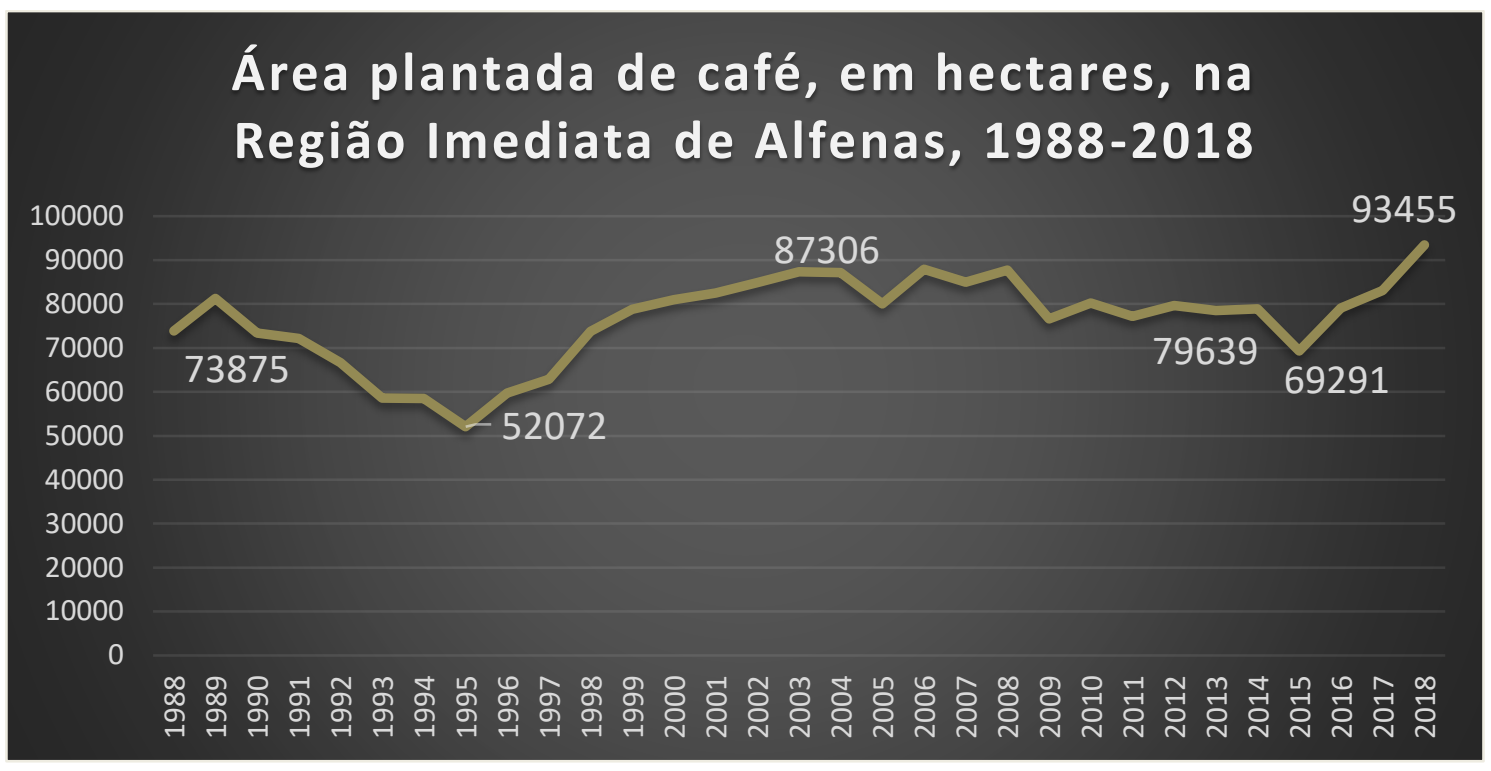

Figura 9 - Área plantada de soja na Região Imediata de Alfenas - MG, entre 1988 e 2017.

Fonte: Pesquisa Agrícola Municipal do IBGE, 1988-2017. Elaboração: Flamarion Dutra Alves.

Algumas oscilações ocorreram no período estudado, porém, sempre manteve a predominância da atividade agrícola na região, e em 2018 passou dos 93 mil hectares plantados de café na região, mostrando a consolidação dessa atividade nos municípios, nos quais vão se especializando cada vez mais para atender essa demanda.

A presença de cooperativas na região é uma característica importante para a monopolização do território pelo capital (OLIVEIRA, 2016), e amplia a difusão da cafeicultura entre os agricultores familiares e consequentemente a commoditização do território captura o pequeno produtor, e não apenas os médios e grandes.

Dentre elas destacam-se a Cooperativa Agrária de Machado (COOPAMA) presente em Alfenas, Machado e Poço Fundo; Cooperativa Regional de Cafeicultores em Guaxupé (COOXUPÉ) presente em Alfenas, Campos Gerais, Alterosa, Areado e Conceição da Aparecida; Cooperativa dos Cafeicultores de Campos Gerais e Campo do Meio (COOPERCAM) presente em Campos Gerais e Campo do Meio; Coopercitrus Cooperativa de Produtores Rurais (COOPERCITRUS) em Alfenas; Cooperativa Agropecuária de Boa Esperança (CAPEBE) em Campo do Meio; Cooperativa Mista Agropecuária de Paraguaçu (COOMAP) em Paraguaçu; Cooperativa dos Cafeicultores da Zona de Três Pontas (COCATREL) em Campos Gerais e a Cooperativa Agropecuária de Cássia (COOPASSA). Vale citar as cooperativas que produzem cafés orgânicos, a Cooperativa dos Agricultores Familiares de Poço Fundo e Região (COOPFAM) presente em Poço Fundo e a Cooperativa dos Camponeses Sul Mineiros (CAMPONESA) em Campo do Meio.

Essas cooperativas fornecem insumos, matéria-prima, assistência técnica, algumas fornecem crédito, além de garantir os canais de comercialização. Fora as cooperativas, há diversas empresas de logística, assistência técnica, armazenagens, torra e moagem, compra e venda de grãos. 
Em 2018, todos municípios da região produziram quantidades significativas de café (Figura 10), e três municípios estão entre os maiores produtores de café do Brasil

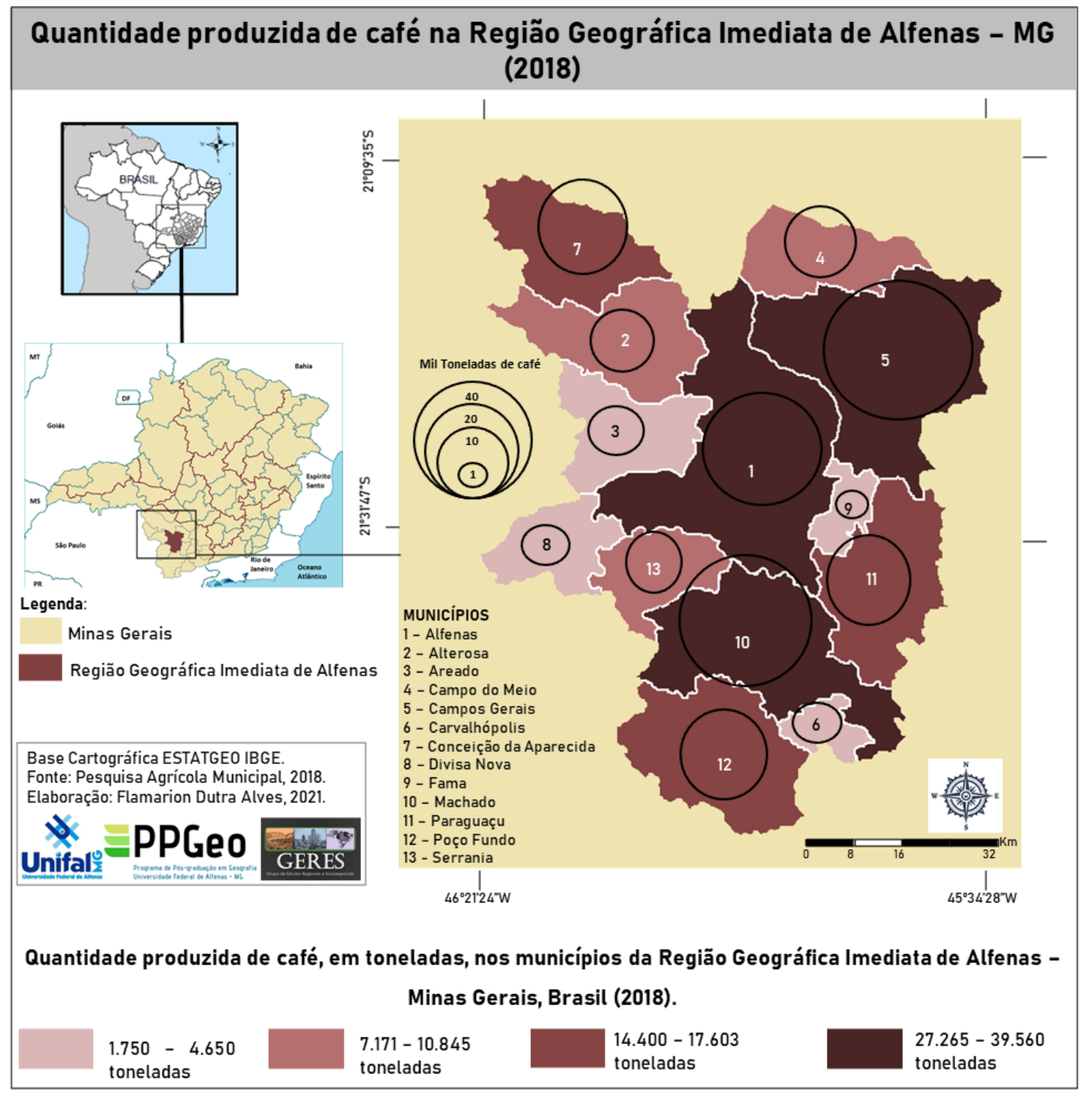

Figura 10 - Quantidade produzida de café, em toneladas, na Região Geográfica Imediata de Alfenas - MG, 2018.

Fonte: Pesquisa Agrícola Municipal, 2018. Elaboração: Flamarion Dutra Alves.

A produção de café em 2018 totalizou quase 188 mil toneladas de café, desse total, Campos Gerais liderou com 39.560 toneladas, sendo o terceiro município no Brasil com maior quantidade produzida, Machado destaca-se com 35.912 toneladas e o sétimo município com maior quantidade produzida no país, e por fim, Alfenas com 27.265 toneladas de café e ocupa a $21^{\mathrm{a}}$ posição no ranking de municípios produtores de café no Brasil.

Os dados confirmam a commoditização do território, e o café sendo a principal atividade econômica que funcionaliza boa parte das cidades da região, criando uma dependência econômica, com consequências ambientais e alimentares negativas com o avanço do agronegócio. 


\section{Considerações Finais}

A questão agrária regional tem mostrado as implicações do modelo baseado no agronegócio, de uma diversidade produtiva e alimentar à uma monocultura destinada a exportação. A redução de áreas para a policultura, tem relação com a baixa ocupação territorial da agricultura familiar, os incentivos creditícios e financeiros ao agronegócio, tem ampliado a commoditização do território e a presença de grandes propriedades.

Nesse período de 30 anos estudados, constata-se como as mudanças no espaço regional são dinâmicas e como a mundialização da agricultura interferiu na paisagem rural e na organização produtiva e alimentar na Região Imediata de Alfenas.

A tendência é de uma ampliação dessa especialização funcional das cidades pequenas, sobretudo, pela cafeicultura, articulando o campo-cidade e o local-global. Entretanto, o Estado brasileiro, grande financiador do agronegócio, é o principal responsável pela commoditização do território, que deveria ampliar as políticas para a agricultura familiar, bem como diminuir a disparidade na estrutura fundiária regional.

\section{Referências}

ALVES, Flamarion Dutra. Cidades pequenas no sul de Minas Gerais: ruralidades presentes no território. In: FERREIRA, Marta Marujo; VALE, Ana Rute. (Orgs.) Dinâmicas Geográficas no Sul de Minas Gerais. Curitiba: Appris, 2018. p.107-127.

ALVES, Flamarion Dutra. Apontamentos teórico-metodológicos sobre a ruralidade. Revista Rural \& Urbano. Recife. v.6, .1, 2021. p.27-46.

ALVES, Flamarion Dutra; LINDNER, Michele. Agronegócio do café no sul de Minas Gerais: territorialização, mundialização e contradições. OKARA: Geografia em debate. João Pessoa, v.14, n.2, 2020. p.433-451.

ALVES, Flamarion Dutra; VALE, Ana Rute do. (Orgs.) Faces da agricultura familiar na diversidade do rural brasileiro. Curitiba: Appris, 2016.

BRANQUINHO, Evânio dos Santos; SILVA, Letícia Silvério da. A reestruturação das cidades médias: o caso de Alfenas no sul de Minas Gerais. In: FERREIRA, Marta Marujo; VALE, Ana Rute. (Orgs.) Dinâmicas Geográficas no Sul de Minas Gerais. Curitiba: Appris, 2018. p.79-106-48.

COCA, Estevan. L. F.; ALVES, Flamarion Dutra; PISANI, Rodrigo José; SAMSONAS, H. P ; FERNANDES, F. B.; SOUZA JÚNIOR, S. A. A luta pela/na terra em tempos de instabilidade institucional: o Acampamento Quilombo Campo Grande, em Campo do Meio - MG. Boletim DATALUTA, v. 131, p. 2-9, 2018.

DIAS, Leila Christina. Redes: emergência e organização. In: CASTRO, Iná Elias de; GOMES, Paulo Cesar da Costa; CORRÊA, Roberto Lobato (Org).

Geografia: conceitos e temas. 12.ed. Rio de Janeiro: Bertrand Brasil, 2009. p.143-162. 
GALEANO, Eduardo. As veias abertas da América Latina. Tradução Sérgio Faraco. 13. Reimpressão. Porto Alegre: L\&PM, 2019.

GUIDA, Larissa Chiulli; ALVES, Flamarion Dutra. Cafeicultura especializada na mesorregião sul/sudoeste de Minas: a organização espacial produtiva. XXI Encontro Nacional de Geografia Agrária. Anais... Uberlândia. p.1-17, 2012.

IBGE - Divisão Regional do Brasil em Regiões Geográficas Imediatas e Regiões Geográficas Intermediárias. IBGE, Coordenação de Geografia. Rio de Janeiro: IBGE, 2017.

IBGE - A Geografia do café. IBGE, Coordenação de Geografia. - Rio de Janeiro : IBGE, 2016.

KAGEYAMA, Angela A. Desenvolvimento rural: conceitos e aplicações ao caso brasileiro. Porto Alegre: Editora da UFRGS, 2008.

IBGE - Censo Agropecuário, 2017. Disponível em:

https://sidra.ibge.gov.br/pesquisa/censo-agropecuario/censo-agropecuario2017 Acesso em: 08 de dezembro de 2021.

IBGE - Censo Agropecuário, 2006. Disponível em:

https://sidra.ibge.gov.br/pesquisa/censo-agropecuario/censo-agropecuario2006/segunda-apuracao Acesso em: 10 de novembro de 2021.

IBGE - Censo Agropecuário, 1995/1996. Disponível em:

https://sidra.ibge.gov.br/pesquisa/censo-agropecuario/censo-agropecuario1995-1996 Acesso em: 11 de dezembro de 2021.

INCRA - Instituto Nacional de Colonização e Reforma Agrária. Informações gerais sobre os assentamentos da Reforma Agrária, 2017. Disponível em: https://painel.incra.gov.br/sistemas/index.php Acesso em: o8 de dezembro de 2021.

LUCAS, Kelson S.; VALE, Ana Rute. Assentamento Primeiro do Sul: passado de luta, presente de resistência e futuro de incertezas. Geografia Ensino \&

Pesquisa, v. 18, n. 1, p. 7-22, jan./abr. 2014.

OLIVEIRA, Ariovaldo Umbelino. Mundialização da Agricultura

Brasileira. São Paulo: Iandé Editorial, 2016.

RUA, João. Ressignificação do rural e as relações cidade-campo: uma contribuição geográfica. Revista da ANPEGE, Fortaleza, ano 2, n. 2, p. -66. 2005 .

SANTOS, Henrique Faria dos. Modernização da agricultura e relação campocidade: uma análise a partir do agronegócio cafeeiro no município de Alfenas MG. Caminhos de Geografia. Uberlândia, v.15, n.51, 2014. p.154-171.

SANTOS, Milton. A natureza do espaço: técnica e tempo, razão e emoção. 4.ed. São Paulo: EDUSP, 2006.

SEDA - Secretaria do Estado de Desenvolvimento Agrário (Alfenas, MG), et al. Laudo socioeconômico e produtivo das comunidades rurais da área da CAPIA, Campo do Meio - MG. Disponível em:

http://dx.doi.org/10.13140/RG.2.2.14628.09600 . Acesso em: o8 de dezembro de 2021. 
VALE, Ana Rute do. A agricultura familiar no contexto do agronegócio do café no Sul/Sudoeste de Minas: variações sobre o mesmo tema. In: FERREIRA, Marta Marujo; VALE, Ana Rute. (Orgs.) Dinâmicas Geográficas no Sul de Minas Gerais. Curitiba: Appris, 2018. p.17-48.

VALE, Ana Rute et al. Reprodução social e agroecologia nos Assentamentos Primeiro do Sul e Nova Conquista II de Campo do Meio - MG. Revista

Retratos de Assentamentos. v.22, n.2, 2019. p.215-240. 